\title{
COVID-19 Mid-term Impact on Hepatocellular Carcinoma in Patients With Hepatitis C Chronic Infection
}

\author{
SILVIU GULER-MARGARITIS ${ }^{1,2}$, ADRIANA MERCAN-STANCIU ${ }^{1,3}$, LETITIA TOMA $^{1,3}$, DANIEL RUSIE ${ }^{4}$, \\ TEODORA ISAC ${ }^{1,3}$, MIHAI DODOT ${ }^{1,3}$, ANCA ZGURA ${ }^{1,5}$, NICOLAE BACALBASA ${ }^{1}$, BOGDAN HAINEALA ${ }^{1,2}$, \\ DUMITRU CRISTINEL BADIU ${ }^{1,6}$, DRAGOS SERBAN ${ }^{1,7}$ and ELENA LAURA ILIESCU ${ }^{1,3}$ \\ ${ }^{1}$ Carol Davila University of Medicine and Pharmacy, Bucharest, Romania; \\ ${ }^{2}$ Department of Urology, Fundeni Clinical Institute, Bucharest, Romania; \\ ${ }^{3}$ Department of Internal Medicine II, Fundeni Clinical Institute, Bucharest, Romania; \\ ${ }^{4}$ Department of General Surgery, Clinical Emergency Hospital, Bucharest, Romania; \\ ${ }^{5}$ Department of Oncology-Radiotherapy, \\ "Prof Dr Alexandru Trestioreanu” Institute of Oncology, Bucharest, Romania; \\ ${ }^{6}$ General Surgery Department, Bagdasar Arseni Clinical Emergency Hospital, Bucharest, Romania; \\ ${ }^{7}$ Department of Surgery, University Emergency Hospital, Bucharest, Romania
}

\begin{abstract}
Background/Aim: Liver injury has been frequently reported in association with SARS-CoV-2 infection, but data are still lacking regarding the impact of pre-existing liver damage and neoplasia on SARS-CoV-2 infection outcome and vice-versa. This study aimed to assess the effects of SARSCoV-2 infection on hepatocellular carcinoma (HCC) in chronic hepatitis $C$ virus (HCV) infected patients, both in therapeutic-naïve and patients treated with direct acting antivirals. Patients and Methods: We conducted a retrospective cohort study on 21 patients with a personal history of HCV infection, that have been diagnosed with different forms of HCC and who were subsequently infected with SARS-CoV-2. Patients were monitored by liver function tests, tumoral markers, blood cell count, and coagulation profile periodically. Results: Solitary HCC nodules were predominant among the subjects who achieved sustained virologic response, while multinodular and infiltrative patterns were mostly prevalent among the treatment-naïve group. Most patients had mild and moderate COVID-19 infections. Conclusion: Within the current global pandemic
\end{abstract}

This article is freely accessible online.

Correspondence to: Dumitru-Cristinel Badiu , "Carol Davila" University of Medicine and Pharmacy, 37 Dionisie Lupu Street, District 2, 020021 Bucharest, Romania. E-mail: doctorcristianbadiu@yahoo.com

Key Words: COVID-19, direct-acting antivirals, hepatocellular carcinoma, hepatitis $\mathrm{C}$ virus infection, SARS-CoV-2. crisis, cancer patients are highly vulnerable and in need of constant monitoring. Among patients with HCC, the ones with cured $\mathrm{HCV}$ infection may be at a lower risk of fatality than those with active HCV infection, when diagnosed with SARS-CoV-2 infection.

Hepatocellular carcinoma (HCC) represents one of the most prevalent malignancies in the world, as well as a leading cause of cancer-related mortality (1). The World Health Organization approximates that over 1 million individuals will die from liver cancer in 2030 (2, 3). Among the wellknown factors involved in liver cancer development, hepatitis $\mathrm{C}$ virus (HCV) chronic infection is associated with a 15- to 20 - fold increased risk for $\mathrm{HCC}(4,5)$; the annually estimated likelihood of $\mathrm{HCC}$ occurrence is $3 \%$ in patients with cirrhosis and active $\mathrm{HCV}$ infection (6). The use of direct-acting antivirals (DAAs) has led to a remarkable progress in $\mathrm{HCV}$ infection treatment, showing high efficacy and a very good safety profile, even in patients with decompensated cirrhosis. DAAs therapy resulted in significantly higher sustained virologic response (SVR) rates in over $95 \%$ of the cases, in all HCV genotypes (7). However, successful antiviral therapy does not completely obliterate the risk of HCC occurrence; therefore, it is highly essential that HCC screening never stops in these patients $(8,9)$. Moreover, except for increasing the likelihood of hepatic malignancy, HCV chronic infection is responsible for a large variety of extrahepatic manifestations (including metabolic disorders, extrahepatic malignancies, autoimmune or inflammatory disorders), and therefore, is considered a systemic disease, rather than just a liver condition $(4,10-13)$. 
Within the last year, the medical world has encountered a significant challenge, represented by severe acute respiratory syndrome coronavirus 2 (SARS-CoV-2) - the fifth betacoronavirus known to infect humans, which has been named coronavirus disease 2019 (COVID-19) pandemic (14). Since this virus has emerged in late December 2019, more than 30 million people have been infected worldwide and mortality is continuously rising.

Currently, HCV infection represents an undeniably important comorbidity in patients infected with SARS-CoV2 , with pre-existing chronic liver disease (CLD) being potentially responsible for worse outcomes following SARSCoV-2 infection. One possible explanation is the association of advanced liver disease with immune dysregulation, systemic inflammation, coagulopathy, and intestinal dysbiosis - conditions that could promote a more severe COVID-19 evolution (15). On the other hand, SARS-CoV-2 itself may represent a newly emerged liver aggressor, and hepatic manifestations are currently recognized as an important element of COVID-19 - with liver biochemistry alterations found in $15-65 \%$ of the cases $(16,17)$.

This study aimed to assess the effects of SARS-CoV-2 infection on $\mathrm{HCC}$ in chronic HCV-infected patients, both in therapeutic-naïve and patients treated with DAAs.

\section{Patients and Methods}

We conducted a prospective observational study on 21 patients with a personal history of $\mathrm{HCV}$ infection, that have been diagnosed with different forms of HCC and who subsequently contracted SARSCoV-2 infection. The study was approved by the local Ethics Committee and was performed from early April 2020 to midDecember 2020. An informed written consent was taken from all the subjects and all the records were confidential.

Over $42 \%$ of these patients had been administered DAA therapy (either ombitasvir/paritaprevir/ritonavir and dasabuvir or ledipasvir/sofosbuvir) and had achieved SVR prior to HCC diagnosis, while the rest of them $(57.14 \%)$ were treatment-naïve. For the latter category of subjects, viral infection was assessed by quantitative $\mathrm{HCV}$ ribonucleic acid (RNA) tests, that showed a high viral load in all patients, with more than 850,000 IU/l. Liver fibrosis was evaluated by Fibromax in all 21 patients, resulting in 14 patients with F4 degree of fibrosis (cirrhotic patients) and 7 patients with F3 degree of fibrosis.

Inclusion criteria for the study were: history of HCV chronic infection, with or without prior DAAs treatment, and documented de novo HCC either by computerized tomography (CT) scan or magnetic resonance imaging (MRI). It is important to mention that, for patients with undetectable viral load consecutive to DAA treatment, HCC was documented at 6 months or more after achieving SVR. In accordance with current guidelines, all patients with a history of $\mathrm{HCV}$ infection are routinely monitored every 6 months, in our clinic, even after SVR is achieved (18) and documented SARS-CoV-2 infection, by reverse transcription polymerase chain reaction, has been cured at least one month prior to the first visit to our clinic (all subjects were diagnosed with COVID-19 between April 2020 and June 2020); at the time of
SARS-CoV-2 infection, no HCC targeted therapeutic measures were performed for any of the patients.

The exclusion criteria were: patients that discontinued surveillance, due to COVID-19 pandemic of for personal reasons; hepatitis B virus or HIV co-infection; decompensated cirrhosis; other concomitant or previous malignant process.

Medical data were retrieved from the electronic records, as well as physical source documents. This strategy allowed us to include and analyze important parameters that were being assessed during COVID-19 hospitalization, and compare them with the data we achieved before and after SARS-CoV-2 infection. Therefore, the following parameters were evaluated before and during COVID-19, as well as one and 6 months after coronavirus infection: alanine transaminase (ALT), aspartate aminotransferase (AST), total bilirubin (TB), alkaline phosphatase (AP), gamma-glutamyl transferase (GGT), serum albumin, alpha-fetoprotein (AFP), blood cell count, coagulation profile. Also, all patients in both groups underwent imaging examinations, before contracting SARS-CoV-2 infection, as well as one-month and six months post COVID-19, such as: ultrasonography, CT and, in some cases, MRI.

Retrieved data were analyzed using the statistical software SPSS 18.0 (SPSS Inc., Chicago, IL, USA). Numerical values are expressed as mean $+/$ - standard deviation. Values were compared by using the ANOVA test (a $p$-value $\leq 0.05$ was considered statistically significant).

\section{Results}

We retrospectively collected and analyzed data from 21 patients infected with HCV genotype $1 \mathrm{~b}$ and diagnosed with HCC, who subsequently contracted the SARS-CoV-2 infection. Most of these HCV-infected patients (57.14\%) were treatment-naïve, while the rest $(42.86 \%)$ underwent DAA therapy (either ombitasvir/paritaprevir/ritonavir and dasabuvir or ledipasvir/sofosbuvir) and had achieved SVR prior to HCC diagnosis. Further baseline characteristics are presented in Table I.

Assessment of fibrosis degree indicated predominance of F4 (with a total of 14 patients, representing over $66 \%$ of the total population). As mentioned in the inclusion criteria, all F4 patients had compensated cirrhosis. Within the patient cohort, the prevalence of HCC types was similar (7 patients with solitary HCC, 8 patients with multinodular HCC and 6 patients with the infiltrative type), but the distribution of HCC types was different within each study group. Among the treatment-naïve group, multinodular and infiltrative forms were the most prevalent $(50 \%$ and $41.66 \%)$ and the infiltrative pattern affected only patients with fibrosis F4. The mean size for the diffuse lesions in these patients was $9.2 \mathrm{~cm}$. By comparison, among the subjects that achieved SVR, solitary HCC nodules were predominant (two thirds of all cases), followed by multinodular HCC, while the infiltrative type was only reported in one patient. The mean size of the focal lesions in the latter group was $4.1 \mathrm{~cm}$.

All patients that presented with an infiltrative HCC pattern were evaluated by both CT scan and MRI. Typical MRI findings were hypo-intensity on T1-weighted images and $\mathrm{T} 2$ 
Table I. Baseline characteristics of the study group.

\begin{tabular}{|c|c|c|c|c|c|c|}
\hline \multirow[b]{2}{*}{$\begin{array}{l}\text { Total number } \\
\text { of pts }(21)\end{array}$} & \multicolumn{3}{|c|}{$\begin{array}{l}\text { Treatment-naïve HCV infection } \\
\qquad(12 \text { pts }-57.14 \%)\end{array}$} & \multicolumn{3}{|c|}{$\begin{array}{l}\text { SVR achieved post DAAs } \\
\quad(9 \mathrm{pts}-42.86 \%)\end{array}$} \\
\hline & $\begin{array}{c}\text { Solitary HCC } \\
\text { nodule } \\
\mathrm{n}=1 \mathrm{pt} \\
(8.33 \%)\end{array}$ & $\begin{array}{l}\text { Multi-nodular } \\
\text { HCC } \\
\mathrm{n}=6 \mathrm{pts} \\
(50 \%)\end{array}$ & $\begin{array}{c}\text { Infiltrative/Diffuse } \\
\text { HCC } \\
n=5 \text { pts }(41.66 \%) \\
\text { (3 pts with PVT) }\end{array}$ & $\begin{array}{l}\text { Solitary HCC } \\
\text { nodule } \\
\mathrm{n}=6 \mathrm{pts} \\
(66.66 \%)\end{array}$ & $\begin{array}{l}\text { Multi-nodular } \\
\text { HCC } \\
\mathrm{n}=2 \mathrm{pts} \\
(22.22 \%)\end{array}$ & $\begin{array}{c}\text { Infiltrative/Diffuse } \\
\text { HCC } \\
\mathrm{n}=1 \mathrm{pt} \\
(11.11 \%)\end{array}$ \\
\hline Mean Age & $48.23+/-15.02$ & $53.83+/-17.45$ & $51.21+/-21.83$ & $48.33+/-18.13$ & $51.87+/-16.75$ & $53.78+/-21.05$ \\
\hline $\begin{array}{l}\text { Gender }- \text { female } \\
(13 \text { pts }-61.90 \%)\end{array}$ & $1 \mathrm{pt}(100 \%)$ & 3 pts $(50 \%)$ & 3 pts $(60 \%)$ & 4 pts $(66.66 \%)$ & $1 \mathrm{pt}(50 \%)$ & 1 pt (100\%) \\
\hline $\begin{array}{l}\text { F4 Fibrosis } \\
(14 \text { pts }-66.66 \%)\end{array}$ & 0 & 3 pts $(50 \%)$ & 5 pts $(100 \%)$ & 4 pts $(66.66 \%)$ & $1 \mathrm{pt}(50 \%)$ & $1 \mathrm{pt}(100 \%)$ \\
\hline $\begin{array}{l}\text { F3 Fibrosis } \\
(7 \text { pts }-33.33 \%)\end{array}$ & $1 \mathrm{pt}(100 \%)$ & 3 pts $(50 \%)$ & 0 & 2 pts $(33.33 \%)$ & $1 \mathrm{pt}(50 \%)$ & 0 \\
\hline
\end{tabular}

HCC: Hepatocellular carcinoma; SVR: sustained virologic response; DAA: direct acting antiviral; pt: patient.

Table II. Patients' distribution, according to COVID-19 severity.

\begin{tabular}{|c|c|c|c|c|c|c|}
\hline \multirow[b]{2}{*}{$\begin{array}{l}\text { Total number } \\
\text { of pts }(21)\end{array}$} & \multicolumn{3}{|c|}{$\begin{array}{l}\text { Treatment-naïve HCV infection } \\
\qquad(12 \text { pts }-57.14 \%)\end{array}$} & \multirow[b]{2}{*}{$\begin{array}{c}\text { Solitary HCC } \\
\text { nodule } \\
\text { n=6 pts } \\
(66.66 \%)\end{array}$} & \multicolumn{2}{|c|}{$\begin{array}{l}\text { SVR achieved post DAAs } \\
\quad(9 \mathrm{pts}-42.86 \%)\end{array}$} \\
\hline & $\begin{array}{c}\text { Solitary HCC } \\
\text { nodule } \\
\mathrm{n}=1 \mathrm{pt} \\
(8.33 \%)\end{array}$ & $\begin{array}{c}\text { Multi-nodular } \\
\text { HCC } \\
n=6 \text { pts } \\
(50 \%)\end{array}$ & $\begin{array}{c}\text { Infiltrative/Diffuse } \\
\text { HCC } \\
n=5 \text { pts }(41.66 \%) \\
\text { (3 pts with PVT) }\end{array}$ & & $\begin{array}{c}\text { Multi-nodular } \\
\text { HCC } \\
n=2 \text { pts } \\
(22.22 \%)\end{array}$ & $\begin{array}{c}\text { Infiltrative/Diffuse } \\
\text { HCC } \\
\mathrm{n}=1 \mathrm{pt} \\
(11.11 \%)\end{array}$ \\
\hline \multicolumn{7}{|l|}{ COVID-19 } \\
\hline $\begin{array}{l}\text { Asymptomatic } \\
(1 \mathrm{pt}-4.76 \%)\end{array}$ & - & - & - & $1 \mathrm{pt}$ & - & - \\
\hline Mild & & & & & & \\
\hline$(9$ pts $-42.85 \%)$ & $1 \mathrm{pt}$ & $2 \mathrm{pts}$ & $1 \mathrm{pt}$ & $4 \mathrm{pts}$ & $1 \mathrm{pt}$ & - \\
\hline $\begin{array}{l}\text { Moderate } \\
(7 \mathrm{pts}-33.33 \%)\end{array}$ & - & 3 pts & $2 \mathrm{pts}$ & $1 \mathrm{pt}$ & $1 \mathrm{pt}$ & - \\
\hline $\begin{array}{l}\text { Severe } \\
(4 \mathrm{pts}-19.04 \%)\end{array}$ & - & $1 \mathrm{pt}$ & $2 \mathrm{pts}$ & - & - & $1 \mathrm{pt}$ \\
\hline
\end{tabular}

HCV: Chronic hepatitis C virus; HCC: hepatocellular carcinoma; pt: patient; SVR: sustained virologic response; DAA: direct acting antiviral.

hyperintensity; 3 of the 6 patients $(50 \%)$ with infiltrative HCC also presented portal vein thrombosis (PVT). It is worth mentioning that all 3 patients with PVT were treatment-naïve: one patient was diagnosed with PVT before COVID-19, and two patients were diagnosed with PVT at the 6 months follow up post COVID-19.

According to the severity of the SARS-CoV-2 infection, patients were divided into four categories: asymptomatic, mild, moderate, and severe cases.

Mild disease was defined as the presence of COVID-19 symptoms (such as fever, cough, fatigue, anorexia, shortness of breath, myalgias, sore throat, nasal congestion, headache, diarrhea, nausea and vomiting, anosmia, ageusia) without evidence of viral pneumonia or hypoxia. Moderate disease was represented by pneumonia, with obvious clinical signs (fever, cough, dyspnea, tachypnea) but no signs of severe pneumonia, including $\mathrm{SpO} 2 \geq 90 \%$ on room air. Severe COVID-19 was considered as severe pneumonia when at least one of the following signs were present: respiratory rate $>30$ breaths/min; severe respiratory distress; or $\mathrm{SpO} 2<90 \%$ on room air. Table II presents the distribution of patients according to COVID-19 severity.

All four severe patients received Continuous Positive Airway Pressure (CPAP). None of them required orotracheal intubation. Only one patient from the DAAs treated subgroup was asymptomatic, but he too was hospitalized for surveillance reasons, due to the presence of personal comorbidities (age, liver disease, active malignancy). Most patients (as reported for the total group) had mild and moderate disease $(42.85 \%$ and $33.33 \%)$, while severe 
Table III. Evolution of the main biological parameters before, during, and after COVID-19 for treatment-naïve HCV-infected patients with HCC.

\begin{tabular}{|c|c|c|c|c|c|c|c|c|c|c|c|c|}
\hline \multirow{4}{*}{ Total (21 pts) } & \multicolumn{12}{|c|}{$\begin{array}{l}\text { Treatment-naïve HCV infection } \\
\qquad(12 \text { pts }-57.14 \%)\end{array}$} \\
\hline & \multicolumn{4}{|c|}{$\begin{array}{l}\text { Solitary HCC nodule } \\
\quad \mathrm{n}=1 \mathrm{pt}(8.33 \%)\end{array}$} & \multicolumn{4}{|c|}{$\begin{array}{c}\text { Multi-nodular HCC } \\
n=6 \text { pts }(50 \%)\end{array}$} & \multicolumn{4}{|c|}{$\begin{array}{c}\text { Infiltrative/Diffuse HCC } \\
n=5 \text { pts }(41.66 \%)\end{array}$} \\
\hline & \multirow[t]{2}{*}{$\begin{array}{l}\text { Pre- } \\
\text { COV }\end{array}$} & \multirow[t]{2}{*}{$\begin{array}{l}\text { During } \\
\text { COV }\end{array}$} & \multicolumn{2}{|c|}{$\begin{array}{l}\text { Post-COVID } \\
\text { follow-up }\end{array}$} & \multirow[t]{2}{*}{$\begin{array}{l}\text { Pre- } \\
\text { COV }\end{array}$} & \multirow[t]{2}{*}{$\begin{array}{l}\text { During } \\
\text { COV }\end{array}$} & \multicolumn{2}{|c|}{$\begin{array}{l}\text { Post-COVID } \\
\text { follow-up }\end{array}$} & \multirow[t]{2}{*}{$\begin{array}{l}\text { Pre- } \\
\text { COV }\end{array}$} & \multirow[t]{2}{*}{$\begin{array}{l}\text { During } \\
\text { COV }\end{array}$} & \multicolumn{2}{|c|}{$\begin{array}{l}\text { Post-COVID } \\
\text { follow-up }\end{array}$} \\
\hline & & & 1 month & 6 months & & & 1 month & 6 months & & & 1 month & 6 months \\
\hline $\operatorname{ALT}(\mathrm{U} / \mathrm{ml})$ & 59 & 198 & 103 & 65 & 81 & 203 & 143 & 120 & 90 & 255 & 179 & 121 \\
\hline AST $(\mathrm{U} / \mathrm{ml})$ & 77 & 233 & 121 & 81 & 99 & 243 & 169 & 132 & 112 & 278 & 199 & 140 \\
\hline Albumin $(\mathrm{g} / \mathrm{dl})$ & 3.1 & 2.1 & 2.9 & 2.8 & 3.0 & 2.0 & 2.7 & 3.1 & 2.4 & 2.03 & 2.3 & 2.27 \\
\hline $\mathrm{TB}(\mathrm{mg} / \mathrm{dl})$ & 2.7 & 2.93 & 2.87 & 2.89 & 2.99 & 3.1 & 3.15 & 3.09 & 3.15 & 3.03 & 3.08 & 3.1 \\
\hline $\operatorname{AFP}(\mathrm{ng} / \mathrm{ml})$ & 723 & 799 & 760 & 735 & 764 & 855 & 809 & 777 & 869 & 951 & 907 & 885 \\
\hline
\end{tabular}

HCC: Hepatocellular carcinoma; ALT: alanine transaminase; AST: aspartate aminotransferase; AFP: alpha-fetoprotein; TB: total bilirubin; pt: patient.

Table IV. Evolution of the main biological parameters before, during, and after COVID-19 for DAA-treated patients (who achieved SVR) with HCC.

\begin{tabular}{|c|c|c|c|c|c|c|c|c|c|c|c|c|}
\hline \multirow{4}{*}{ Total (21 pts) } & \multicolumn{12}{|c|}{$\begin{array}{l}\text { Achieved SVR post DAAs } \\
\quad(9 \mathrm{pts}-42.85 \%)\end{array}$} \\
\hline & \multicolumn{4}{|c|}{$\begin{array}{l}\text { Solitary HCC nodule } \\
\mathrm{n}=6 \mathrm{pt}(66.66 \%)\end{array}$} & \multicolumn{4}{|c|}{$\begin{array}{l}\text { Multi-nodular HCC } \\
n=2 \text { pts }(22.22 \%)\end{array}$} & \multicolumn{4}{|c|}{$\begin{array}{c}\text { Infiltrative/Diffuse HCC } \\
n=1 \mathrm{pt}(11.11 \%)\end{array}$} \\
\hline & \multirow[t]{2}{*}{$\begin{array}{l}\text { Pre- } \\
\text { COV }\end{array}$} & \multirow[t]{2}{*}{$\begin{array}{l}\text { During } \\
\text { COV }\end{array}$} & \multicolumn{2}{|c|}{$\begin{array}{l}\text { Post-COVID } \\
\text { follow-up }\end{array}$} & \multirow[t]{2}{*}{$\begin{array}{l}\text { Pre- } \\
\text { COV }\end{array}$} & \multirow[t]{2}{*}{$\begin{array}{l}\text { During } \\
\text { COV }\end{array}$} & \multicolumn{2}{|c|}{$\begin{array}{l}\text { Post-COVID } \\
\text { follow-up }\end{array}$} & \multirow[t]{2}{*}{$\begin{array}{l}\text { Pre- } \\
\text { COV }\end{array}$} & \multirow[t]{2}{*}{$\begin{array}{l}\text { During } \\
\text { COV }\end{array}$} & \multicolumn{2}{|c|}{$\begin{array}{l}\text { Post-COVID } \\
\text { follow-up }\end{array}$} \\
\hline & & & 1 month & 6 months & & & 1 month & 6 months & & & 1 month & 6 months \\
\hline $\operatorname{ALT}(\mathrm{U} / \mathrm{ml})$ & 39 & 88 & 57 & 43 & 55 & 108 & 87 & 63 & 77 & 135 & 111 & 81 \\
\hline AST (U/ml) & 48 & 97 & 65 & 54 & 69 & 129 & 104 & 77 & 85 & 144 & 125 & 95 \\
\hline Albumin $(\mathrm{g} / \mathrm{dl})$ & 3.4 & 3.1 & 3.3 & 3.21 & 3.0 & 3.1 & 2.91 & 3.17 & 2.95 & 3.03 & 2.99 & 3.01 \\
\hline $\mathrm{TB}(\mathrm{mg} / \mathrm{dl})$ & 2.31 & 2.43 & 2.37 & 2.5 & 2.56 & 2.6 & 2.59 & 2.66 & 2.90 & 3.01 & 3.03 & 3.1 \\
\hline $\operatorname{AFP}(\mathrm{ng} / \mathrm{ml})$ & 187 & 291 & 256 & 231 & 233 & 289 & 267 & 240 & 269 & 312 & 297 & 277 \\
\hline
\end{tabular}

HCV: Chronic hepatitis C virus; HCC: hepatocellular carcinoma; SVR: sustained virologic response; DAA: direct acting antiviral; ALT: alanine transaminase; AST: aspartate aminotransferase; AFP: alpha-fetoprotein; TB: total bilirubin; pt: patient.

COVID-19 patients represented $19 \%$ of the total number. The majority of severe COVID-19 cases (75\%, 3 out of 4 patients) were $\mathrm{HCC}$ patients with an active $\mathrm{HCV}$ infection (treatment-naïve). Half of the patients with an infiltrative HCC developed severe pneumonia. This data suggests that, among patients with $\mathrm{HCC}$, the ones with cured HCV infection may be at a lower risk of fatality than those with active viral hepatitis $\mathrm{C}$ infection, when diagnosed with SARS-CoV-2 infection. Also, infiltrative HCC was associated with a higher incidence of severe COVID-19 pneumonia, while recently cured $\mathrm{HCV}$ patients mostly developed asymptomatic and mild disease (66.66\%).

Liver biochemistry abnormalities were reported in both groups, even before SARS-CoV-2 infection, due to the pre- existing liver disease, but a more marked elevation was observed in patients with no history of antiviral treatment. Evolution of the main biological parameters, for both subgroups, is presented in detail in Table III and Table IV. In both of the subgroups, a similar pattern in the dynamics of liver biochemistry (transaminases, bilirubin, albumin, AFP) was observed. ALT and AST presented an important elevation $(\times 3$ times) during COVID-19 (by comparison to the start values), followed by a slight decrease at 1 month after the disease, and appeared to slowly diminish even more; the identified values at 6 months follow-up were comparable with the ones before SARS-CoV-2 infection. Total bilirubin and albumin levels showed no statistically significant alterations within the two subgroups; however, TB was higher and albumin was lower in 
treatment-naïve patients. AFP levels also increased during COVID-19 (Table III and Table IV), followed by a descending pattern after resolution of the disease, and the levels at 6 months follow-up were similar to those before COVID-19.

\section{Discussion}

It is highly noticeable that, within our study groups, the previously-treated subjects had more circumscribed and better delineated lesions, with a higher prevalence of solitary masses compared to untreated ones. However, at this point, literature data regarding $\mathrm{HCC}$ occurrence and pattern after DAA therapy is conflicting. Some studies suggest that, after using DAAs tumor growth is accelerated, possibly due to a rapid HCV clearance that might be responsible for ceasing the intrahepatic immune response stimulated by chronic infection (leading to a blockage in NK cells activation) and, subsequently, favoring the proliferation of secluded neoplastic cells that had been, until that moment, dormant (19-21). In contrast, several reports showed a lower risk of HCC occurrence in patients with SVR post DAA treatment compared to those untreated $(22,23)$. Although controversy persists with regard to this subject, we emphasize the necessity of performing a rigorous follow-up for all patients with a history of HCV-infection (either treated or therapeutically naïve).

Typically, when associated with PVT, HCC is characterized by a worse prognosis, a higher likelihood of complications, and a mediocre tolerance to treatment. Clinically, patients with PVT present large tumor sizes, increased number of tumoral masses, higher tumor grading, as well as higher serum alpha-fetoprotein levels (24). These characteristics were also observed in our 3 patients with PVT. The patients diagnosed with PVT at 6 months after COVID-19 resolution received palliative therapy with a systemic agent (sorafenib), as indicated by the oncologist.

One patient with treatment-naïve HCV infection, HCC and PVT diagnosed before COVID-19, was also examined by the oncology specialist, with the recommendation of sorafenib, but in his case, treatment was delayed due to various reasons. The COVID-19 pandemic lockdown initially resulted in the discontinuation of scheduled visits, followed by the patient's admission into another hospital (being discharged after approximatively one month of hospitalization).

Within the current global pandemic crisis, patients with cancer are considered highly vulnerable. Furthermore, a recent research revealed that cancer patients had a higher risk of severe clinical events associated with SARS-CoV-2 infection, than cancer-free patients (25). However, current clinical studies are still limited by relatively small cohorts and also by a high heterogeneity in the course of the disease.

It is a well-known fact that liver plays a key-role in all metabolic processes, being not only the body's largest macrophage reservoir, but also having the ability to trigger immune responses through pathogen recognition receptors (PRR), such as toll-like receptors (TLRs). Moreover, the liver's dual blood supply facilitates antigen arrival from the gut (26). Therefore, it is expected that the liver would take part in the viral response against SARS-CoV-2 since the virus binds to the angiotensin-converting enzyme 2 (ACE2) receptor, which is found mainly in cholangiocytes, but also in the vascular endothelium and perivenular hepatocytes (27). Within the normal hepatocytes, ACE2 expression is typically low, but in the cirrhotic liver increased expression is often observed within the cirrhotic nodules (27). Moreover, hypoxia results in an upregulation of ACE2 receptor expression on hepatocytes; a study by Paizis et al. suggests that the expression rate increases with the duration of hypoxia (28). Therefore, in COVID-19 associated hypoxia, there is a high probability that hepatocytes get directly infected by the virus (via ACE2 receptor), especially in cirrhotic patients (27). Also, the possibility of other SARS-CoV-2 receptors that mediate direct liver damage during COVID-19 deserves further inquiry. Apart from the direct hepatic effect, SARS-CoV-2 infection has been associated with an important systemic immune response and the release of proinflammatory cytokines, resulting in further liver damage associated with COVID-19 (27). Regarding our study, persistent liver damage was evident in both subgroups, most probably as a result of both direct and indirect SARS-CoV-2 effects.

COVID-19 is caused by the SARS-CoV-2 - a newly emerged virus that is capable of causing liver injury by both direct and indirect mechanisms (direct cytopathic effect, immune-mediated damage), leading to an exacerbation of preexisting liver disease. The vulnerability of patients with cancer (including HCC) is a well-known fact in the light of the current COVID-19 pandemic. Our study revealed that patients with $\mathrm{HCC}$ and active $\mathrm{HCV}$ infection had a higher prevalence of severe SARS-CoV-2 pneumonia. Also, infiltrative HCC was associated with a higher incidence of severe pulmonary disease. Liver biochemical abnormalities persisted about 6 months after COVID-19 resolution, with a similar frequency regardless of the presence/absence of the previous $\mathrm{HCV}$ antiviral treatment. However, our current clinical study, as well as other current studies, are limited by relatively small cohorts. Therefore, we highly encourage further research on this subject, as well as a continuous monitoring of patients that developed COVID-19 pneumonia, especially in the presence of comorbidities, such as preexisting liver damage or neoplastic lesions. Also, we emphasize the necessity of performing a rigorous follow-up for all patients with a history of $\mathrm{HCV}$ infection, either treated or therapeutically naïve.

\section{Conflicts of Interest}

The Authors declare that they have no competing interests in relation to this study. 


\section{Authors' Contributions}

A M-S, LT, DR, DS were responsible writing of the manuscript. $\mathrm{AZ}, \mathrm{BH}$, and $\mathrm{DCB}$ were responsible for reviewing and editing the manuscript. TI, MD and NB made substantial contributions to the conception or design of the work. ELI was responsible for critically reviewing the manuscript. All Authors read and approved the final manuscript.

\section{References}

1 Global Burden of Disease Liver Cancer Collaboration, Akinyemiju T, Abera S, Ahmed M, Alam N, Alemayohu MA, Allen C, AlRaddadi R, Alvis-Guzman N, Amoako Y, Artaman A, Ayele TA, Barac A, Bensenor I, Berhane A, Bhutta Z, Castillo-Rivas J, Chitheer A, Choi JY, Cowie B, Dandona L, Dandona R, Dey S, Dicker D, Phuc H, Ekwueme DU, Zaki MS, Fischer F, Fürst T, Hancock J, Hay SI, Hotez P, Jee SH, Kasaeian A, Khader Y, Khang YH, Kumar A, Kutz M, Larson H, Lopez A, Lunevicius R, Malekzadeh R, McAlinden C, Meier T, Mendoza W, Mokdad A, Moradi-Lakeh M, Nagel G, Nguyen Q, Nguyen G, Ogbo F, Patton G, Pereira DM, Pourmalek F, Qorbani M, Radfar A, Roshandel G, Salomon JA, Sanabria J, Sartorius B, Satpathy M, Sawhney M, Sepanlou S, Shackelford K, Shore H, Sun J, Mengistu DT, TopórMądry R, Tran B, Ukwaja KN, Vlassov V, Vollset SE, Vos T, Wakayo T, Weiderpass E, Werdecker A, Yonemoto N, Younis M, Yu C, Zaidi Z, Zhu L, Murray CJL, Naghavi M and Fitzmaurice C: The Burden of Primary Liver Cancer and underlying etiologies from 1990 to 2015 at the global, regional, and national level: Results from the Global Burden of Disease Study 2015. JAMA Oncol 3(12): 1683-1691, 2017. PMID: 28983565. DOI: 10.1001/ jamaoncol.2017.3055

2 World Health Organization. Projections of mortality and causes of death, 2016 to 2060. Available at: http://www.who.int/ healthinfo/global_burden_disease/projections/en/ [Last accessed on August 10, 2021]

3 Villanueva A: Hepatocellular carcinoma. N Engl J Med 380(15): 1450-1462, 2019. PMID: 30970190. DOI: 10.1056/ NEJMra1713263

4 Iliescu EL, Toma L, Diaconu C, Zgura A, Bacalbasa N and Mercan-Stanciu A: Type 2 diabetes mellitus and the risk of hepatocellular carcinoma in chronic Hepatitis $\mathrm{C}$ patients treated with direct acting antivirals. Proceedings of 6th International Conference on Interdisciplinary Management of Diabetes Mellitus and its Complications INTERDIAB 2020, pp. 148-154, 2020.

5 Gigi E, Lagopoulos VI and Bekiari E: Hepatocellular carcinoma occurrence in DAA-treated hepatitis $\mathrm{C}$ virus patients: Correlated or incidental? A brief review. World J Hepatol 10(9): 595-602, 2018. PMID: 30310537. DOI: 10.4254/wjh.v10.i9.595

6 Meringer H, Shibolet $\mathrm{O}$ and Deutsch L: Hepatocellular carcinoma in the post-hepatitis $\mathrm{C}$ virus era: Should we change the paradigm? World J Gastroenterol 25(29): 3929-3940, 2019. PMID: 31413528. DOI: 10.3748/wjg.v25.i29.3929

7 Baumert TF, Berg T, Lim JK and Nelson DR: Status of directacting antiviral therapy for hepatitis $\mathrm{C}$ virus infection and remaining challenges. Gastroenterology 156(2): 431-445, 2019. PMID: 30342035. DOI: 10.1053/j.gastro.2018.10.024

8 Toyoda H, Yasuda S, Kiriyama S, Tanikawa M, Hisanaga Y, Kanamori A, Kitabatake S, Yamamoto S, Shiota S, Furoi M,
Koyabu T, Furukawa D, Kumada T and Sumida Y: Impact of COVID-19 pandemic on surveillance of hepatocellular carcinoma: a study in patients with chronic hepatitis $\mathrm{C}$ after sustained virologic response. GastroHep: 10.1002/ygh2.418, 2020. PMID: 32837333. DOI: 10.1002/ygh2.418

9 Iliescu E, Mercan-stanciu A, Toma L, Ioanitescu E, Dumitru R and Rusie D: Hepatocellular carcinoma in the setting of Interferon-free treatment for chronic HCV hepatitis - experience of a single center. Hepatoma Research 4(1): 3, 2018. DOI: 10.20517/2394-5079.2017.48

10 Iliescu L, Mercan-Stanciu A, Toma L and Ioanitescu ES: A severe case of hyperglycemia in a kidney transplant recipient undergoing interferon-free therapy for chronic hepatiTIS C. Acta Endocrinol (Buchar) 14(4): 533-538, 2018. PMID: 31149309. DOI: $10.4183 / \mathrm{aeb} .2018 .533$

11 Iliescu L, Mercan-Stanciu A, Ioanitescu ES and Toma L: Hepatitis C-associated B-cell non-Hodgkin lymphoma: A pictorial review. Ultrasound Q 34(3): 156-166, 2018. PMID: 30020272. DOI: 10.1097/RUQ.0000000000000369

12 Iliescu L, Herlea V, Toma L and Orban C: Association between chronic HCV hepatitis, membranoproliferative glomerulopathy and cutaneous sarcoidosis. J Gastrointestin Liver Dis 24(1): 8, 2015. PMID: 25822425. DOI: 10.15403/jgld.2014.1121.lil

13 Iliescu EL, Mercan-Stanciu A and Toma L: Safety and efficacy of direct-acting antivirals for chronic hepatitis $\mathrm{C}$ in patients with chronic kidney disease. BMC Nephrol 21(1): 21, 2020. PMID: 31948406. DOI: 10.1186/s12882-020-1687-1

14 Turnquist C, Ryan BM, Horikawa I, Harris BT and Harris CC: Cytokine storms in cancer and COVID-19. Cancer Cell 38(5): 598-601, 2020. PMID: 33038939. DOI: 10.1016/j.ccell. 2020.09.019

15 Marjot T, Webb GJ, Barritt AS 4th, Moon AM, Stamataki Z, Wong VW and Barnes E: COVID-19 and liver disease: mechanistic and clinical perspectives. Nat Rev Gastroenterol Hepatol 18(5): 348-364, 2021. PMID: 33692570. DOI: 10.1038/ s41575-021-00426-4

16 Lozano-Sepulveda SA, Galan-Huerta K, Martínez-Acuña N, Arellanos-Soto D and Rivas-Estilla AM: SARS-CoV-2 another kind of liver aggressor, how does it do that? Ann Hepatol 19(6): 592-596, 2020. PMID: 32858226. DOI: 10.1016/j.aohep. 2020.08 .062

17 Youssef M, H Hussein M, Attia AS, M Elshazli R, Omar M, Zora G, S Farhoud A, Elnahla A, Shihabi A, Toraih EA, S Fawzy $\mathrm{M}$ and Kandil E: COVID-19 and liver dysfunction: A systematic review and meta-analysis of retrospective studies. J Med Virol 92(10): 1825-1833, 2020. PMID: 32445489. DOI: 10.1002/ jmv. 26055

18 European Association for the Study of the Liver Electronic address: easloffice@easloffice.eu, Clinical Practice Guidelines Panel: Chair, EASL Governing Board representative and Panel members: EASL recommendations on treatment of hepatitis C: Final update of the series J Hepatol 73(5): 1170-1218, 2020. PMID: 32956768. DOI: 10.1016/j.jhep.2020.08.018

19 Romano A, Capra F, Piovesan S and Alberti A: Incidence and pattern of 'de novo' hepatocellular carcinoma in HCV patients treated with oral DAAs. Paper presented at: $67^{\text {th }}$ Meeting of the American Association for the Study of Liver Diseases: Liver Meeting; Boston, MA, USA, 11-15 November 2016.

20 Serti E, Chepa-Lotrea X, Kim YJ, Keane M, Fryzek N, Liang TJ, Ghany M and Rehermann B: Successful interferon-free 
therapy of chronic hepatitis $\mathrm{C}$ virus infection normalizes natural killer cell function. Gastroenterology 149(1): 190-200.e2, 2015. PMID: 25754160. DOI: 10.1053/j.gastro.2015.03.004

21 Abdelaziz AO, Nabil MM, Abdelmaksoud AH, Shousha HI, Hashem MB, Hassan EM, Salah A, Omran DA and Elbaz TM: Tumor behavior of hepatocellular carcinoma after hepatitis $\mathrm{C}$ treatment by direct-acting antivirals: comparative analysis with non-direct-acting antivirals-treated patients. Eur J Gastroenterol Hepatol 31(1): 75-79, 2019. PMID: 30199473. DOI: 10.1097/ MEG.0000000000001264

22 Pascut D, Pratama MY and Tiribelli C: HCC occurrence after DAA treatments: molecular tools to assess the post-treatment risk and surveillance. Hepat Oncol 7(2): HEP21, 2020. PMID: 32647566. DOI: $10.2217 /$ hep-2020-0010

23 Ioannou GN, Green PK and Berry K: HCV eradication induced by direct-acting antiviral agents reduces the risk of hepatocellular carcinoma. J Hepatol, 2017. PMID: 28887168 DOI: $10.1016 / \mathrm{j} . j h e p .2017 .08 .030$

24 Connolly GC, Chen R, Hyrien O, Mantry P, Bozorgzadeh A, Abt $\mathrm{P}$ and Khorana AA: Incidence, risk factors and consequences of portal vein and systemic thromboses in hepatocellular carcinoma. Thromb Res 122(3): 299-306, 2008. PMID: 18045666. DOI: $10.1016 /$ j.thromres.2007.10.009

25 Liang W, Guan W, Chen R, Wang W, Li J, Xu K, Li C, Ai Q, Lu W, Liang H, Li S and He J: Cancer patients in SARS-CoV-2 infection: a nationwide analysis in China. Lancet Oncol 21(3): 335-337, 2020. PMID: 32066541. DOI: 10.1016/S14702045(20)30096-6

26 Heymann F and Tacke F: Immunology in the liver-from homeostasis to disease. Nat Rev Gastroenterol Hepatol 13(2): 88-110, 2016. PMID: 26758786. DOI: 10.1038/nrgastro. 2015.200
27 Lizardo-Thiebaud MJ, Cervantes-Alvarez E, Limon-de la Rosa N, Tejeda-Dominguez F, Palacios-Jimenez M, Méndez-Guerrero O, Delaye-Martinez M, Rodriguez-Alvarez F, Romero-Morales B, Liu WH, Huang CA, Kershenobich D and Navarro-Alvarez $\mathrm{N}$ : Direct or collateral liver damage in SARS-CoV-2-infected patients. Semin Liver Dis 40(3): 321-330, 2020. PMID: 32886936. DOI: $10.1055 / \mathrm{s}-0040-1715108$

28 Paizis G, Tikellis C, Cooper ME, Schembri JM, Lew RA, Smith AI, Shaw T, Warner FJ, Zuilli A, Burrell LM and Angus PW: Chronic liver injury in rats and humans upregulates the novel enzyme angiotensin converting enzyme 2. Gut 54(12): 17901796, 2005. PMID: 16166274. DOI: 10.1136/gut.2004.062398

29 Feng G, Zheng KI, Yan QQ, Rios RS, Targher G, Byrne CD, Poucke SV, Liu WY and Zheng MH: COVID-19 and liver dysfunction: Current insights and emergent therapeutic strategies. J Clin Transl Hepatol 8(1): 18-24, 2020. PMID: 32274342. DOI: $10.14218 / \mathrm{JCTH} .2020 .00018$

30 Yang Z, Xu M, Yi JQ and Jia WD: Clinical characteristics and mechanism of liver damage in patients with severe acute respiratory syndrome. Hepatobiliary Pancreat Dis Int 4(1): 6063, 2005. PMID: 15730921.
Received July 18, 2021

Revised August 20, 2021

Accepted August 23, 2021 